\title{
Microsatellite markers for population genetic studies of the blowfly Chrysomya putoria (Diptera: Calliphoridae)
}

\author{
Rosangela Aparecida Rodrigues ${ }^{1,2}$, Ana Maria Lima de Azeredo-Espin ${ }^{1,2}$, Tatiana Teixeira Torres ${ }^{1 /+}$ \\ ${ }^{1}$ Centro de Biologia Molecular e Engenharia Genética ²Departamento de Genética e Evolução, Universidade Estadual de Campinas, \\ Campinas, SP, Brasil
}

The investigation of the genetic variation and population structure of Chrysomya species is of great interest for both basic and applied research. However, very limited genetic information is available for this genus across its geographical distribution. Here, we describe 12 polymorphic microsatellite loci isolated from Chrysomya putoria with expected heterozygosities ranging from 0.1402-0.8312. These markers are of potential applied interest for forensic entomologists and for the characterisation of the genetic structure of C. putoria from recently colonised regions, with great promise for understanding the colonisation dynamics and spread of the genus Chrysomya in the New World.

Key words: invasive species - forensic entomology - myiasis

Chrysomya putoria is a blowfly native to Africa where it is of considerable medical and sanitary importance as a mechanical vector of pathogens and as a secondary myiasis agent in man and animals (Zumpt 1965, Guimarães \& Papavero 1999). Larvae of C. putoria feed on decomposing substrates (Souza \& Linhares 1997). Due to this habit, it is also important in forensic entomology, which utilise information from insects in death investigations (Greenberg 1991). Among other applications, such insects can be used to estimate the post-mortem interval and to determine whether the remains have been relocated.

Originally, C. putoria was restricted to the Old World and its native range extended from Tanzania to Congo (Zumpt 1965). Circa 1975, C. putoria was introduced to the New World, showing a rapid rate of dispersal across the Americas (Laurence 1988). Three other Old World Chrysomya species (Chrysomya albiceps, Chrysomya megacephala and Chrysomya rufifacies) have also been introduced into the New World (Guimarães \& Papavero 1999) and it is believed that these species have displaced native species through competition for substrate and ecological niches (Laurence 1988). Each of these invader species spread with different dispersion rates and routes for establishing themselves across the continent, with varying success. Although $C$. putoria spread more rapidly, it was later outnumbered by $C$. albiceps and $C$. megacephala (Junqueira 2002). The characterisation of populations of these Chrysomya species provides an opportunity to study basic processes in population biology and may provide novel insights into the colonisation dynamics and spread of invasive taxa.

Financial support: FAPESP (03/01458-9), CNPq (471132/01-2)

+Corresponding author: tttorres@unicamp.br

Received 17 April 2009

Accepted 16 July 2009
One essential component for successful population genetics studies is the availability of suitable molecular markers. Among the classes of molecular markers, microsatellite loci stand out as co-dominant markers with a high number of alleles per locus, high polymorphism and a high expected heterozygosity value. Because of these features, microsatellites have been extremely useful for investigating population structure, gene flow and mating systems even in populations that have low levels of allozyme and mitochondrial gene variation (Goldstein \& Schlötterer 1999). As a part of an effort to characterise Chrysomya populations from South America we initially isolated microsatellite markers for $C$. albiceps (Torres \& Azeredo-Espin 2008). In this report, we present novel loci for $C$. putoria.

For library construction, we used a pool of eight pupae from a laboratory culture. Genomic DNA was extracted using the Puregene ${ }^{\mathrm{TM}}$ DNA isolation kit (Gentra Systems, Minneapolis, MN).

For the polymorphism assessment, adults of $C$. putoria were collected from two sites in Brazil, São João da Boa Vista, São Paulo (21 $58^{\circ} 11^{\prime \prime} S$ 46 47'56”W), and Belém, Pará (1²7'18'S 48³0'09'W). Adults of C. putoria were captured by hand-net using decomposing liver as bait and frozen at $-70^{\circ} \mathrm{C}$ before DNA preparation. DNA was extracted from individual flies using a standard phenol/chloroform procedure (Infante-Vargas \& Azeredo-Espin 1995).

Genomic DNA from the colony-bred pupae was digested with RsaI (Invitrogen, Carlsbad, CA) and bluntended DNA fragments were ligated to oligonucleotide adapters. Fragments containing $\mathrm{AC}$ and $\mathrm{AG}$ repeats were selected by hybridisation to biotinylated oligonucleotides complementary to the repetitive sequence and recovered by magnetic beads linked to streptavidin. Microsatellite-rich fragments were amplified by PCR, ligated into pGEM-T easy plasmid (Promega, Madison, WI) and cloned in Escherichia coli XL1-Blue cells.

Plasmids from individual colonies were prepared and the sequence of the inserts was determined using an ABI Prism Terminator Cycle sequencing kit and an ABI 377 
automated sequencer (Applied Biosystems, Foster City, CA). Primer pairs complementary to sequences flanking the repeat element were designed using Primer3 software (Rozen \& Skaletsky 2000).

The characterised loci were amplified using conditions described in Torres and Azeredo-Espin 2008) with locus-specific annealing temperatures (Table I). PCR products were analysed on denaturing $6 \%$ polyacrylamide gels in a sequencing electrophoresis apparatus and the alleles were visualised using a standard silver staining protocol (Blum et al. 1987). PCR products of one cloned allele for each locus (using 1:1000 dilution of plasmid DNAs) and the $10 \mathrm{bp}$ DNA ladder (Invitrogen, Carlsbad, CA) were used as size references.

The number of alleles per locus, the allele size range and the observed and expected heterozygosities were determined for the polymorphic loci. Each locus was tested for deviations from Hardy-Weinberg equilibrium expectations using exact tests implemented in Genepop (Raymond \& Rousset 1995). The genotypic disequilibrium between pairs of loci was also calculated using Genepop. Sequential Bonferroni corrections (Rice 1989) were applied for multiple tests performed simultaneously.
Despite the great interest in C. putoria for both basic and applied research in topics such as the dynamics of invasive species, forensic entomology and human health, no study has been published on the genetic characterisation of geographic populations of this species. Since the first requirement for any population genetic study is the availability of a reliable set of polymorphic markers, we isolated and characterised a core set of twelve polymorphic microsatellite loci for C. putoria.

We sequenced 130 clone inserts from the enriched library, 52 of which had a microsatellite. Among these, 20 were chosen for designing primers for the amplification of loci. Of the 20 loci characterised, 12 were polymorphic and could be amplified consistently, one was monomorphic and primers for the remaining loci failed to produce a reliable product. Primer sequences, microsatellite motifs and other related information for each locus are detailed in Table I.

Polymorphism was assessed using wild-caught individuals of $C$. putoria from two sampling sites in Brazil. In the two C. putoria populations, the number of alleles per locus ranged from 3-8, with an average of 5.3. This

TABLE I

Characterization of the microsatellite loci isolated from Chrysomya putoria

\begin{tabular}{|c|c|c|c|c|c|c|c|}
\hline Locus & $\begin{array}{r}\text { Genbank } \\
\text { accession }\end{array}$ & Primer sequence $\left(5^{\prime} \rightarrow 3^{\prime}\right)$ & $\begin{array}{c}\mathrm{T}_{\mathrm{a}} \\
\left({ }^{\circ} \mathrm{C}\right)\end{array}$ & $\begin{array}{l}\text { Repeat motif in } \\
\text { the cloned allele }\end{array}$ & $\begin{array}{l}\text { Size of the cloned } \\
\text { allele (bp) }\end{array}$ & $\begin{array}{l}\text { Allele size } \\
\text { range } \\
(b p)\end{array}$ & $\begin{array}{l}\text { Number } \\
\text { of alleles }\end{array}$ \\
\hline CP02 & - & $\begin{array}{c}\text { F:CGGAACCTTTATCCTTCC } \\
\text { R:TGCACTTGTTGTTCAACTTC }\end{array}$ & 56 & $(\mathrm{AC})_{3} \mathrm{ATACAA}(\mathrm{AC})_{7}$ & 126 & - & 1 \\
\hline CP04 & FJ447469 & $\begin{array}{c}\text { F:ACTGCATTGATATGTGTATTG } \\
\text { R:GAACATTTTTCCAACCAC }\end{array}$ & 58 & $(\mathrm{AC})_{8}$ & 148 & $142-146$ & 3 \\
\hline CP05 & FJ447470 & $\begin{array}{l}\text { F:CCTTTACTTTAAGCCCTTCC } \\
\text { R:GGTTTGGTGGAAAAGAGAC }\end{array}$ & 62 & $(\mathrm{AG})_{10} \mathrm{~A}(\mathrm{AG})_{2}$ & 157 & $157-177$ & 6 \\
\hline CP06 & FJ447471 & $\begin{array}{l}\text { F:AAACACTATTGCAAAATACC } \\
\text { R:ATTTCCTTCCTATTTGTTG }\end{array}$ & 54 & $(\mathrm{GA})_{9} \mathrm{GC}(\mathrm{GA})_{2}$ & 156 & $150-166$ & 7 \\
\hline СР07 & FJ447472 & $\begin{array}{c}\text { F:AGGGAAACAGACCATAACG } \\
\text { R:GCATAAATGCATATTTGTAAAG }\end{array}$ & 58 & $(\mathrm{CA})_{18}$ & 167 & $149-167$ & 7 \\
\hline СР09 & FJ447473 & $\begin{array}{c}\text { F:AAGTTTACATTCATTCGTTGG } \\
\text { R:CGATTTGCCATCCCTATG }\end{array}$ & 58 & $(\mathrm{AG})_{11}$ & 139 & $123-141$ & 6 \\
\hline CP10 & FJ447474 & $\begin{array}{c}\text { F:TGTTCAGCAATTCTGTCG } \\
\text { R:GGGTCTAAAAAGTGCATGG }\end{array}$ & 56 & $(\mathrm{GA})_{8}$ & 149 & $149-157$ & 3 \\
\hline CP12 & FJ447475 & $\begin{array}{c}\text { F:AAGCTTTTACCACACTTG } \\
\text { R:GCATATAGTTGATAATGTCC }\end{array}$ & 58 & $(\mathrm{CA})_{9}$ & 215 & $189-219$ & 5 \\
\hline CP14 & FJ447476 & $\begin{array}{c}\text { F:CCTCAATATACATACAACAAGC } \\
\text { R:ACGCCAACAAACGTAGAG }\end{array}$ & 58 & $(\mathrm{AC})_{8}$ & 179 & $173-197$ & 8 \\
\hline CP15 & FJ447477 & $\begin{array}{l}\text { F:ACGACAGACCTTGTTATTTG } \\
\text { R:CCAACACACAGAAAATTG }\end{array}$ & 56 & $(\mathrm{AC})_{9}$ & 207 & $199-217$ & 4 \\
\hline CP16 & FJ447478 & $\begin{array}{c}\text { F:TGCGTGTGTATTACATTGC } \\
\text { R:ACCACTACTCAAAGGTCTCG }\end{array}$ & 62 & $\left.(\mathrm{CAA})_{2} \mathrm{TAA} \mathrm{CAA}\right)_{4}$ & 247 & $229-250$ & 4 \\
\hline CP19 & FJ447479 & $\begin{array}{l}\text { F:CCATCAACCAAGTAAATC } \\
\text { R:TAAAGGTTTAGCCTTCAG }\end{array}$ & 54 & $(\mathrm{AC})_{2} \mathrm{AT}(\mathrm{AC})_{8}$ & 124 & $116-124$ & 5 \\
\hline CP20 & FJ447480 & $\begin{array}{l}\text { F:CACATGACCCAAAAGTCC } \\
\text { R:ACCTAAACGGCAACACTG }\end{array}$ & 62 & $(\mathrm{AC})_{8}$ & 200 & $194-204$ & 6 \\
\hline
\end{tabular}

$\mathrm{T}_{\mathrm{a}}$ : annealing temperature. 
TABLE II

Polymorphism assessment on the microsatellite loci isolated from Chrysomya putoria using two geographical populations

\begin{tabular}{|c|c|c|c|c|c|c|c|c|}
\hline \multirow[b]{2}{*}{ Locus } & \multicolumn{4}{|c|}{$\begin{array}{l}\text { São João da Boa Vista, São Paulo } \\
\qquad \mathrm{n}=14\end{array}$} & \multicolumn{4}{|c|}{$\begin{array}{c}\text { Belém, Pará } \\
\mathrm{n}=16\end{array}$} \\
\hline & $\begin{array}{l}\text { Number of } \\
\text { alleles }\end{array}$ & Ho & $\mathrm{He}$ & p-value & $\begin{array}{l}\text { Number of } \\
\text { alleles }\end{array}$ & Ho & $\mathrm{He}$ & $\mathrm{p}$-value \\
\hline CP04 & 3 & 0.1428 & 0.1402 & 1.0000 & 3 & 0.3125 & 0.2802 & 1.0000 \\
\hline CP05 & 4 & 0.1667 & 0.7138 & $0.0000^{a, b}$ & 5 & 0.0714 & 0.7434 & $0.0000^{a, b}$ \\
\hline CP06 & 6 & 0.0000 & 0.8312 & $0.0000^{a, b}$ & 4 & 0.1428 & 0.7143 & $0.0000^{a, b}$ \\
\hline CP07 & 5 & 0.4545 & 0.7099 & 0.1545 & 6 & 0.5333 & 0.6552 & 0.4817 \\
\hline СР09 & 4 & 0.4615 & 0.6062 & 0.0943 & 5 & 0.1428 & 0.8122 & $0.0000^{a}$ \\
\hline CP10 & 2 & 0.0000 & 0.3492 & $0.0010^{a, b}$ & 3 & 0.0000 & 0.6234 & $0.0000^{a, b}$ \\
\hline CP12 & 5 & 0.5714 & 0.8095 & $0.0004^{a, b}$ & 4 & 0.1875 & 0.5343 & $0.0011^{a, b}$ \\
\hline CP14 & 7 & 0.5000 & 0.7884 & 0.0269 & 6 & 0.2667 & 0.7908 & $0.0000^{a}$ \\
\hline CP15 & 3 & 0.0769 & 0.4954 & $0.0003^{a}$ & 3 & 0.1250 & 0.1794 & 0.0926 \\
\hline CP16 & 3 & 0.2143 & 0.4153 & 0.0408 & 3 & 0.2143 & 0.6243 & $0.0033^{a}$ \\
\hline CP19 & 5 & 0.7857 & 0.6772 & 0.6393 & 4 & 0.5333 & 0.6000 & 0.1403 \\
\hline CP20 & 4 & 0.3571 & 0.6190 & $0.0024^{a}$ & 6 & 0.4375 & 0.8125 & 0.0047 \\
\hline
\end{tabular}

$a$ : denotes a significant $(\alpha=0.05)$ deviation from equilibrium after sequential Bonferroni correction (Rice 1989); $b$ : the loci deviating from equilibrium in both populations; He: expected heterozygosity; Ho: observed heterozygosity. The p-values reported are from the tests of Hardy-Weinberg equilibrium.

average was slightly smaller than the average number of alleles observed in $C$. albiceps microsatellites, 5.7 (Torres \& Azeredo-Espin 2008), but both were substantially smaller than the average allele number per locus observed in the native South American Calliphoridae, Chrysomya hominivorax, 7.4 (Torres et al. 2004, Torres \& Azeredo-Espin 2005). The reduced variability at Chrysomya microsatellite loci is in agreement with the expectation that introduced populations show reduced levels of diversity because of founder effects and post-introduction demographic bottlenecks (Dlugosch \& Parker 2008). The comparison of these data to further studies on native populations in Africa using these markers will allow a direct estimation of the effect of bottleneck on the genetic variability of introduced populations.

The observed and expected heterozygosities ranged from $0-0.7857$ and from $0.1402-0.8312$, respectively (Table II). Four loci showed significant heterozygote deficits in both populations. Two and three loci deviated from equilibrium in only one population, São João da Boa Vista and Belém, respectively. No significant linkage disequilibrium was detected after sequential Bonferroni correction.

The significant departures from Hardy-Weinberg equilibrium at multiple loci may result from periodic changes in post-colonisation population size, strong selection effects in the new environment or re-introductions. Alternatively, departures from the equilibrium could be due to the presence of null alleles in the characterised loci. Such artefacts result from mutations such as substitutions, insertions and/or deletions in one or both priming sites. This prevents the binding of the DNA strand and primers, resulting in non-amplification of the allele (Callen et al. 1993). The study of additional populations from the Americas and their historical distributions will shed light onto this question.

The loci described herein will be useful for investigating the structure of $C$. putoria populations from their original distribution as well as dispersal and colonisation dynamics in the invaded regions. The combined analysis of introduced Chrysomya populations will be an important component in understanding processes shaping their evolution after the New World invasion. Furthermore, a comprehensive genetic analysis of $C$. putoria populations using these markers is of potential applied interest for forensic entomologists. Such investigation would be useful in assigning specimens to particular geographic locations and for kinship analysis by providing basic information to infer post-mortem relocation of corpses (Wells \& Stevens 2008).

\section{ACKNOWLEDGEMENTS}

To Alessandra Staffocker, for valuable technical assistance, and to Maria Salete Couto, for maintaining the blowfly colonies.

\section{REFERENCES}

Blum H, Beier H, Gross HJ 1987. Improved silver staining of plant proteins, RNA and DNA in polyacrylamide gels. Electrophoresis 8: 93-99.

Callen DF, Thompson AD, Shen Y, Phillips HA, Richards RI, Mulley JC, Sutherland GR 1993. Incidence and origin of "null" alleles in the (AC)n microsatellite markers. Am J Hum Genet 52: 922-927.

Dlugosch KM, Parker IM 2008. Founding events in species invasions: genetic variation, adaptive evolution and the role of multiple introductions. Mol Ecol 17: 431-449. 
Goldstein D, Schlötterer C 1999. Microsatellites: evolution and applications, Oxford University Press, Oxford, 368 pp.

Greenberg B 1991. Flies as forensic indicators. J Med Entomol 28: 565-577.

Guimarães JH, Papavero N 1999. Myiasis in man and animals in the neotropical region - Bibliographic database, Plêiade/FAPESP, São Paulo, 308 pp.

Infante-Vargas ME, Azeredo-Espin AML 1995. Genetic variability in mitochondrial DNA of screwworm, Cochiomyia hominivorax (Diptera: Calliphoridae), from Brazil. Biochem Genet 33: 737-756.

Junqueira ACM 2002. Utilização do aDNA para estudos genéticoevolutivos relacionados a introdução e dispersão de Chrysomya putoria (Diptera: Calliphoridae) no Brasil, $\mathrm{PhD}$ Thesis, Universidade Estadual de Campinas, Campinas, 192 pp.

Laurence BR 1988. The tropical African latrine blowfly, Chrysomya putoria (Wiedemann). Med Vet Entomol 2: 285-291.

Raymond M, Rousset F 1995. GENEPOP (version 1.2): population genetics software for exact tests and ecumenicism. J Hered 86: $248-249$.

Rice WR 1989. Analyzing tables of statistical tests. Evolution 43: 223-225.
Rozen S, Skaletsky H 2000. Primer3 on the www for general users and for biologist programmers. Methods Mol Biol 132: 365-386.

Souza AM, Linhares AX 1997. Diptera and Coleoptera of potential forensic importance in Southeastern Brazil: relative abundance and seasonality. Med Vet Entomol 11: 8-12.

Torres TT, Azeredo-Espin AML 2005. Development of new polymorphic microsatellite markers for the New World screw-worm Cochliomyia hominivorax (Diptera: Calliphoridae). Mol Ecol Notes 5: 815-817.

Torres TT, Azeredo-Espin AML 2008. Characterization of polymorphic microsatellite markers for the blowfly Chrysomya albiceps (Diptera: Calliphoridae). Mol Ecol Resour 8: 208-210.

Torres TT, Brondani RPV, Garcia JE, Azeredo-Espin AML 2004. Isolation and characterization of microsatellite markers in the new world screw-worm Cochliomyia hominivorax (Diptera: Calliphoridae). Mol Ecol Notes 4: 182-184.

Wells JD, Stevens JR 2008. Application of DNA-based methods in forensic entomology. Annu Rev Entomol 53: 103-120.

Zumpt F 1965. Myiasis in man and animals in the Old World, Butterworths, London, $267 \mathrm{pp}$. 